\title{
WHEN A RITUAL MURDER OCCURRED AT PURIM. THE HARM IN HATE SPEECH
}

\section{Cuando ocurrió un asesinato ritual en Purim. Daño de los discursos de odio}

\section{Raphael Cohen-Almagor}

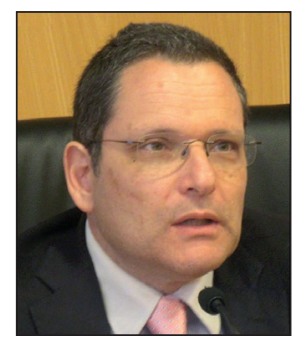

Raphael Cohen-Almagor received his D. Phil. in political theory from Oxford University in 1991, and his B.A. and M.A. from Tel Aviv University. In 1992-1995 he lectured at the Hebrew University Law Faculty. In 1995-2007 he taught at the University of Haifa Law School, Department of Communication, and Library and Information Studies University of Haifa. He has served in various organizations, including as Chairperson of "The second generation to the holocaust and heroism remembrance" organization in Israel; founder and director of the Medical Ethics Think-tank at the Van Leer Jerusalem Institute; member of the Israel Press Council, Chairperson of Library and Information Studies, and founder and director of Center for Democratic Studies, both at the University of Haifa. He is Chair in Politics at the University of Hull, United Kingdom, and director of the Middle East Study Group. In 2008-2009 he served as Acting Deputy Dean for Research at Hull Faculty of Arts and Social Sciences. He has published numerous articles and book chapters in the fields of political science, law, Israel studies, philosophy, media ethics, medical ethics, education, sociology and history.

https://orcid.org/0000-0002-5869-9243

University of Hull, Faculty of Business, Law and Politics, School of Law and Politics Cottingham Road, Hull HU6 7RX, East Riding, UK r.cohen-almagor@hull.ac.uk

\begin{abstract}
This paper aims to address the problem of hate on the Internet. It is opened with a definition of hate speech. Then it discusses hate speech prior to the Internet, during the Internet's early days and at present time. The paper explains some of the ways that hate groups utilise the Internet and their purposes in doing so, examining the content and the functions of hate sites as well as the agenda of hate mongers. Under examination are the issues of propaganda, targeting children and youth, incitement and blood libels. The article is based in the main on a close study of dozens of hate websites.
\end{abstract}

\section{Keywords}

Bigotry; Hate crime; Hate site; Defamation; Websites; Hate speech; Racism; Violence.

\section{Resumen}

Este artículo trata el problema del odio en Internet. Se inicia con una definición de los discursos de odio, para seguidamente describir tales discursos antes de internet, durante los primeros días de internet y en la actualidad. Se explican algunas de las formas en que los grupos racistas utilizan internet y sus propósitos al hacerlo, examinando el contenido y las funciones de las webs que incitan al odio, así como las agendas de sus creadores. Bajo examen están los temas de propaganda dirigida a niños y jóvenes, incitación y libelos de sangre contra los judíos. El artículo se basa principalmente en un estudio detallado de docenas de sitios webs racistas..

\section{Palabras clave}

Fanatismo; Delitos de odio; Webs de incitación al odio; Difamación; Libelo; Discursos de odio; Racismo; Violencia.

Cohen-Almagor, Raphael (2018). "When a ritual murder occurred at Purim. The harm in hate speech". El profesional de la información, v. 27, n. 3, pp. 671-681. 


\section{Introduction ${ }^{1}$}

On June 17, 2015, 21-year-old Dylann Roof entered the Emanuel African Methodist Episcopal Church in downtown Charleston, where a Bible study was under way. The church houses the nation's oldest black congregation south of Baltimore. Roof asked for the senior pastor - the Rev. Clementa Pinckney, and sat next to him. After a while, Roof pulled out a gun, and told the group he had to kill them:

"I have to do it... You rape our women and you're taking over our country. And you have to go." (Potok, 2015).

Roof murdered nine people in cold blood. In his manifesto, Roof wrote that he drew his first racist inspiration from the Council of Conservative Citizens (CCC) website. http://conservative-headlines.com

This incident provides yet another illustration of the direct connection between online hate and hate crimes (for further discussion, see Gerstenfeld, 2017; Cohen-Almagor, 2015; Keats-Citron, 2014).

The aim of this article is to urge all concerned stakeholders to take hate seriously. Its novelty lies in the hard evidence and findings collated here. First, it reports on the results of a long-standing study of dozens of fascist and racist websites, documenting what radical members of the White movement are saying but letting readers judge the severity of the statements. In this respect, the article aims to evoke awareness regarding the mind-set, concerns and language of the people who hate. While not all forms of hate speech lead to hate crimes, still there is sufficient evidence to suggest that speech can and does inspire crime. It is argued that the Internet attracts those who are prone to adopt hateful messages, and that it prompts people into action. It is by no means the only way to spread ideas and to push people to action, but one should not disregard or dismiss the Internet's significance and importance.

There is sufficient evidence to suggest that hate speech can and does inspire crime

I have been studying hate on the Internet for a number of years. This article is the last of a series of articles published since 2009. First came "Holocaust denial is a form of hate speech" (Cohen-Almagor, 2009), and "Countering hate on the Internet - A rejoinder" (Cohen-Almagor, 2010). They were followed by "Fighting hate and bigotry on the Internet" (Cohen-Almagor, 2011), which led to an article in the field of business ethics: "Freedom of expression, Internet responsibility and business ethics: The Yahoo! saga and its aftermath" (Cohen-Almagor, 2012). I then published "Countering hate on the Internet" (Cohen-Almagor, 2014) which supplemented the 2011 article. These two articles summarise what I wish to say about how we should counter hate on the Internet (see also Tworek, 2017). Therefore, the present article does not address this important question. In light of Facebook's growing importance, in 2016 I published "Facebook and Holocaust denial" (Cohen-Almagor, 2016), and most recently I wrote "Taking North American white supremacist groups seriously: The scope and the challenge of hate speech on the Internet" (Cohen-Almagor, 2018) (see also Foxman, 2014). It is advisable to read the present article alongside the others, especially with the 2018 article as this article supplements it. The article shows that Net hate is a stern phenomenon that deserves serious attention, aiming to minimize its violent impact.

The research for this article began some five years ago. Many of the websites I studied are no longer available. This field of studies is problematic as many hate sites are volatile; they close, move around, change names and locations. Quite a few websites used for the writing of this article became defunct by the time I submitted the article for publication.

This field of studies is problematic as many hate sites are volatile; they close, move around, change names and locations

\section{Hate speech}

Hate speech is a significant problem worldwide, especially on the Internet. Net hate is found on thousands of websites, file archives, chat rooms, newsgroups and mailing lists. Hate speech is defined as a bias-motivated, hostile, malicious speech aimed at a person or a group of people because of some of their actual or perceived innate characteristics. It expresses discriminatory, intimidating, disapproving, antagonistic and/or prejudicial attitudes toward those characteristics which include sex, race, religion, ethnicity, colour, national origin, disability, or sexual orientation (Cohen-Almagor, 2011). Hate speech is intended to injure, dehumanize, harass, debase, degrade, and/or victimise the targeted groups, and to foment insensitivity and brutality towards them. A hate site is defined as a site that carries any form of hateful textual, visual, or audio-based rhetoric.

\subsection{Before the Internet}

Prior to the Internet, it was relatively difficult for hate mongers to seek people nation-wide who might be attracted to their ideas. Racist, xenophobic, homophobic and sexist material was distributed by mail, magazines, newspapers, and through telephone answering machines. To spread their beliefs, hate groups also printed leaflets and then handed them out on the streets. Sometimes they encountered hostility of people who did not appreciate their messages. Sometimes the police were called. Hate organizations held rallies in order to promote public and media attention. At times, those rallies ended in court proceedings. ${ }^{2}$

It was relatively difficult, prior to the Internet, for hatemongers to seek out people who are prone to hate. These tend to be the marginal and the alienated, people who by their very nature are disconnected socially and politically. As the human rights activist David Matas eloquently writes, there are no organizations for the marginal, clubs for the alienated, connections amongst the disconnected. With the Internet, hate mongers are less isolated (Matas, 1997) (see also Gerstenfeld, Grant, and Chiang, 2003). The Internet provides them with a convenient infrastructure that did not exist before. It brings people together, facilitates informa- 
tion, confirmation and reassurance, allowing hate mongers to reach into the privacy and isolation of people's homes, to find the vulnerable, those prone to the message of hate speech, wherever they happen to be, to interact with them and to lure them into ideologies of hatred. The Internet is facilitating easy accessibility to hate speech.

\section{People who are prone to hate tend to be the marginal and the alienated, people who by their very nature are disconnec- ted socially and politically}

In the 1970s, the telephone was used to disseminate hatred. For example, the Western Guard Party in Canada had a telephone answering machine which was used for propagating innocuous statements denigrating the Jews. In 1979 , complaints about these messages were lodged with the Canadian Human Rights Commission. The Commission established a tribunal which concluded that the messages constituted a discriminatory practice under s. 13(1) of the Canadian Human Rights Act and ordered the appellants to cease the practice. After a long legal struggle that culminated in the Supreme Court, it was argued that hate propaganda

"produces effects that are deleterious to the objective of equality of opportunity. Thus, there is clearly a rational connection between the restriction on communicating hate messages and the objective of promoting equality for racial and religious minorities" ${ }^{\prime 3}$.

Testimonials of prominent hate mongers are most revealing. Since 1970, when Don Black joined the National Socialist Youth Movement, he has been actively involved in anti-Semitic, racist and anti-immigrant activities. An associate of a notorious hate activist David Duke, Black rose to become leader of the Knights of the Ku Klux Klan, and ran for U.S. Senate from Alabama with the support of the anti-Semitic Willis Carto and Carto's Liberty Lobby, the most important anti-Semitic propaganda organization in the United States. He went on to establish close ties with a number of racist, neo-Nazi organizations, among them the Idaho-based Aryan Nations (Hoffman, 1996). Before the Internet, Black said, people who shared his beliefs had little opportunity to try to spread them, other than through leaflets, small newspapers and rallies (Vaughan, 2017; Bartlett, 2017). But today a relatively inexpensive website can reach millions. ${ }^{4}$ Stormfront.org is one of the top 30,000 sites in the world. In the USA, the site is ranked in the top 13,000 .

http://www.alexa.com/siteinfo/stormfront.org

Stormfront's membership has gone from 5,000 in January 2002 to 286,000 in 2014 (Dickson, 2014; See also Bowman-Grieve, 2009). According to Quantcast, in 2014 roughly 200,000 to 400,000 Americans visited the site every month (Stephens-Davidowitz, 2014).

\subsection{Internet's early days}

Before the World Wide Web became popular, neo-Nazi skinheads depended on Usenet newsgroups such as alt. skinheads to communicate with each other and spread their propaganda. Usenet is a network run by volunteers with common interests. It is a global, decentralized, distributed Internet discussion system that evolved from general purpose architecture. It was conceived by Duke University graduate students Tom Truscott and Jim Ellis in 1979.

http://www.livinginternet.com/u/ui_netnews.htm

Users read and post messages to one or more of a number of newsgroup categories. As the World Wide Web developed, allowing for the spread of information over the Internet through an easy-to-use and flexible format, hate extremists were quick to realize the Web's power. In 1983, West Virginia neo-Nazi publisher George Dietz established the first computer bulletin board system (BBS), called Liberty Bell Net or Info International Network, ${ }^{5}$ on which he posted racist, anti-Semitic, and Holocaust denial material. Dietz was apparently the first White supremacist to launch his material in cyberspace (Berlet, 2000). In 1985, long before most people knew something about the evolving technology, the leader of White Aryan Resistance Tom Metzger created a computer bulletin board (Hamm, 1993; Kaplan, 1995).

https://www.resist.com/index.html

In those years, private bulletin boards began springing up and were quickly employed by a growing number of racist groups. A few hundred such systems titled Patriot Net, Liberty Net and the like were serving the far, racist right in the early 1990s (Stern, 2001-2002). By 1996, a few skinheads sites were already online, including Skin Net, Skinheads USA, and the site for Resistance Records (Kessler, 1999):

http://www.spirit-of-metal.com/label-label-resistance records-l-en.html

The Internet has rapidly become the medium of choice for hatemongers because of its wide access at low cost. Norman Olson, commander of the Michigan Militia Corps, one

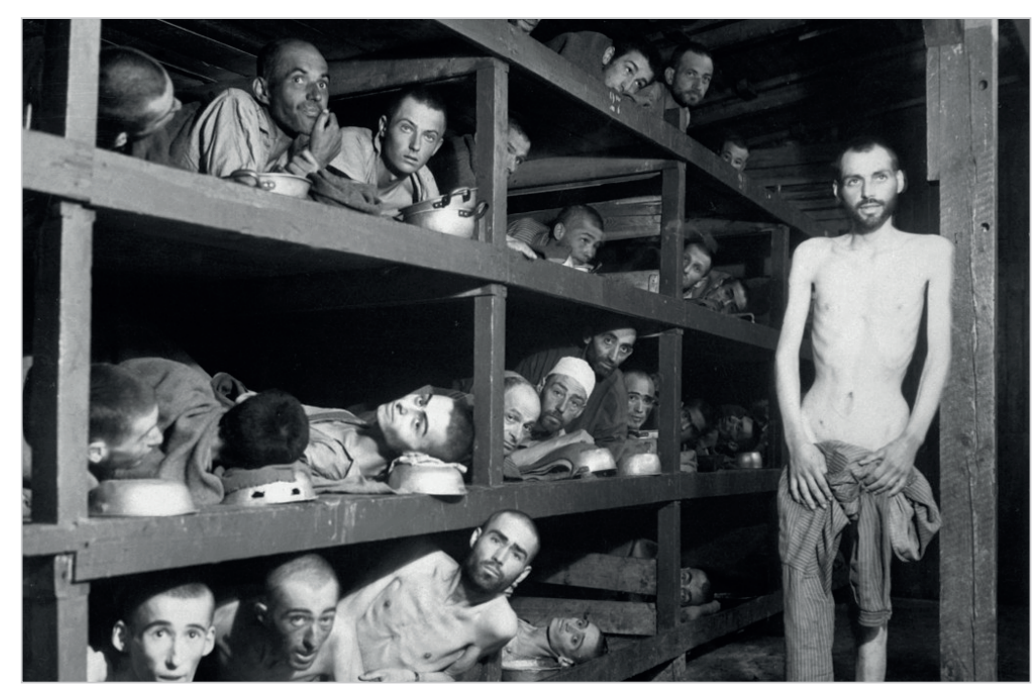

Jewish slave laborers in the Buchenwald concentration camp near Jena, Germany, on April 16, 1945

https://www.jta.org/2011/05/03/news-opinion/world/the-holocaust-from-behind-enemy-lines 
of the many extreme right wing groups using the Internet, has said "Thank God for high tech" (Sandberg, 1994).

\subsection{Nethate: The Internet in the hands of hate mongers}

Indeed, the difference in sheer numbers is most significant. Before the Internet, hate speech was accessible to thousands, those on the mailing lists, those who called in to telephone hate lines, those who could be pamphleteered on the street or in parking lots. Now, through the Internet, hate speech is accessible to millions.

Through the Internet, hate speech is accessible to millions

Hate groups make the most of the Internet and the communication options that are now open to them: websites, blogs, email, chats, discussion forums, Web-based bulletin boards, clubs and groups on social networks and instant messaging (IM). With the help of the Internet, hate groups are able to reach places that were closed for them before, such as schools. Social networking sites are particularly well suited for connecting social outcasts, angry and isolated individuals on the fringe of society who find solace and comfort in cyberspace. Facebook, Twitter and YouTube are used to disseminate hate and to target teens, children and women both for becoming supporters of hate or hate victims (Fuchs, 2014; Werts, 2000; KhosraviNik; Unger, 2015; Foxman, 2014; Plaugic, 2015).

Supremacist messages litter websites, promoting racial superiority and attacking certain religions or gays and lesbians. White supremacist groups such as the Ku Klux Klan, skinheads, Neo-Nazis, and the National Association for the Advancement of White People (Naawp) have websites, blogs, "rants and rave" forums, discussion groups, photos and videos on the Internet:

http://www.theuka.us

http://www.hammerskins.net

http://www.americannaziparty.com

http://dfwdude.webs.com

While a main website is set up by a group's leader, multiple sites are also set up by district or state chapters as well as by individual members. These sites usually contain the history of the sponsoring group, a mission statement, and text by group members. To attract the reader, symbols and pictures offer eye-catching teasers.

http://www.bloodandhonourworldwide.co.uk

On a Nazi site titled "Censure of democracy"

("Today we're the target of the democratic governments; many comrades are in prison, our publications are censured: therefore, we must fight stronger than ever")

you found National-Socialist books, images, flags, symbols, photos, revisionist literature, music of the Third Reich, war articles, hate literature, and links to other sites.

http://thecensureofdemocracy.150m.com (no longer available)

Hate mongers are champions of freedom of expression and of the First Amendment.
- First Amendment Exercise Machine http://www.faem.com

- The Freedom Site http://www.freedomsite.org

- The Canadian Association for Free Expression (CAFE) http://www.canadianfreespeech.com (on April, 24, 2018 I could see only the home page).

They talk and reinforce each other, empowering people who share their beliefs and offend their targets. The dichotomy between "us" and "them" is necessary as it fulfils both functions of creating a sense of belonging and marking the bounds of unity. White supremacist websites and chat groups promulgate the belief that whites are the oppressed group and that society is in danger of being overrun by ignorant, welfare-loving minorities who desire white women. For instance, the Northwest Homeland warned:

"We and our children are being displaced in our own land. Non-Whites are flooding across our borders every day. If current trends continue, White people will be a tiny minortiy (sic.) on this continent by 2050 . By 2100, we will no longer exist in North America."

http://www.northwesthomeland.org/principles.html (no longer available)

Northwest Homeland outlined five basic facts:

- white genocide is real;

- the Germans were the real victims of the Holocaust;

- whites have rights;

- people are in jail for debating the Holocaust, and

- white pride is not a hate crime.

Some sites offered a program for women, Women for Aryan Unity. The Occidental Pan Aryan Crusader.

http://archive.li/JcaV3

The dichotomy between "us" and

"them" is necessary as it fulfils both functions of creating a sense of belonging and marking the bounds of unity

The National Socialist Movement Women's Division believes that through "education, unity, and love, the White Race will flourish above all others, and cover the Earth once again with beauty". It was explained that

"We do not feel the need to separate ourselves from the Movement based on our Femininity. We are strong, and true, and steadfast, and we fight at any cost for the truth. NSM Women walk proudly alongside our men as equals in spirit, and are revered by many" with a clear sense of purpose: "Aryan survival".

"Education and procreation with the intent to further develop our race into strong, effective members of society. Aid and encouragement to our men, to strengthen and uplift them... To have our voices be heard above the masses that they may know the Aryan Soul will never die. Protection of the Aryan Child, without whom we all are doomed, to ensure a better and brighter future for all". NSM Womens (sic.) Division. 


\section{http://wd.nsm88.org}

On April 24, 2018, the site refereed readers to

http://vikingragenetwork.net

In turn, a Czech site, Resistance Women Unity, promoted white supremacist women, offering information on children, mythology and white supremacists serving time in prison: http://women-unity.net (no longer available)

\section{Propaganda}

In hate propaganda, the "other" is represented as a social polluter. The "other" is metaphorically associated with disease and cast as viral presence whose very existence on (often American) soil is sufficient to undermine its social stability and those values which have made it the place where a strong and powerful nation has been built. The foreigner is the enemy (Roversi, 2008). Interestingly, there are quite a few websites related to the Columbine massacre that link the killers to Judaism in sinister ways. The Jews are ruthless killers who inflict destruction and mayhem on gentiles (for instance, Man, 2009).

The opening page of $h t t p: / / k k k k$.net has a mission statement that readers are free to read while listening to the sound of marching drums in which the KKK delineates between "us" and "them", maps the objectives and the enemies. It speaks of love of

"our own race, culture and future no matter what the devil and his world says about us".

The enemy includes "Hollywood drama" controlled by the Jews as well as "Foreign Israeli registered" and "Criminal $A D L$ ". They are aligned with the JDL (Jewish Defence League) that

"bombed more places in the United States than any other known group".

The $K K K$ is forced to fight against great power indeed, including the media, controlled by Jews, the Senate and the House influenced by Jews. This is a difficult task as they all spread lies produced by

"Alien Jew owners from the international jewish banking cartel who run satan's world and system".

http://kkkk.net (no longer available)

The Internet allows the ignorant and the prejudiced to send anonymous messages to those whom they despise, such as officers of black student organizations or Jewish or Arab-American students at major universities (Delgado; Stefancic, 2004). The Vanguard News Network discusses a-la Joseph Goebbels "Jews and Rats... a startling similarity": http://www.vnnforum.com/showthread.php?t=2328

One website promises: The truth will set you free. It explains how Jews control America.

http://wakeupfromyours/umber.com/fact-sheet-jewscontrol-america

\section{Targeting children and youth}

Much effort is invested in appealing to young people. The Klan provides youth news: "News to keep the world's white minority youth informed and hopeful!":
The Knights of the Ku Klux Klan

http://www.kkk.bz/youthnews.htm (no longer available)

Video games, both on the Internet and available for purchase on CDs, teach children that violence is acceptable. A new breed of games, developed by Resistance Records, is prevalent. In one, "Ethnic cleansing", players kill Black and Hispanics in order to gain access to the subway where the Jews are hiding:

https://www.youtube.com/watch?v=xIZCGyVGjMM

During the game, monkey and ape sounds are heard when Blacks are killed, poncho-wearing Latinos say 'I'll take a siesta now!' and 'Ay caramba!' while 'Oy vey!' rings out when Jewish characters are killed. The game features a high level of background detail including various National Alliance signs and posters that appear throughout while racist rock blares on the soundtrack.

Racist groups use computer gaming to promote violence against Blacks, Latinos and Jews

https://www.adl.org/sites/default/files/documents/assets/ pdf/combating-hate/Racist-groups-use-computer-gaming.pdf

Other popular titles include "Nazi wolf 3D", "Zog's nightmare", "KZ manager millennium" in which the player assumes the role of a death camp manager who needs to run it efficiently, "Border patrol" in which you get points for shooting down immigrants trying to cross the border, and "Shoot the Blacks", described as "Blast away the darkies as they appear. An excellent little shooter style game".

https://www.youtube.com/watch?v=pr9-JMJvMqk

https://www.youtube.com/watch?v=ZJZawOyOefc

http://en.metapedia.org/wiki/ZOG\%27s_Nightmare (this page has been deleted).

https://www.youtube.com/watch?v=iPOzseELJI\&list=PLMi46SFJzU-6JJrXQHOQtaiY_PX4qawZq

https://www.youtube.com/watch?v=771pxXhERB4 (no longer available).

https://boardgamegeek.com/boardgame/17408/borderpatrol

http://www.resist.com/racistgames/playborderpatrol/ borderpatrol.htm (no longer available).

http://www.resist.com/racistgames/index.htm

For further discussion, see Terdiman (2004).

It is noted that some mainstream games also have racist connotations. See, for instance, Resident evil 5 (Goldstein, 2009).

One of the world's largest online gaming platforms, Steam, has a thriving community dedicated to glorifying and discussing school shootings. Carless and Sankin counted 173 groups that blatantly promote school shooters (Carless; Sankin, 2018). Many use photos of notorious killers like Elliot Rodger, who murdered six people near UC-Santa Barbara in 2014, in retribution for being rejected by women. The misogyny that drove Rodger's violence is frequently celebrated. There are discussions about whom school shooters should target during future rampages. In addition to school shooting groups, a large number of white supremacist and neo-Nazi groups are also present on Steam (Carless; Sankin, 2018). 
To propagate their ideology better, and to make sure that children will not get "wrong" ideas, some websites encourage parents to take their children out of schools and educate them at home, where they could have direct control on the educational material their children learn. For instance: $h t t p: / / w w w . k k k . b z$ (no longer available) asked:

"Have YOU considered what your children learn at school? Are they learning that homosexuality and lesbianism are cool? Are they learning that interracial dating and marriage is acceptable? Have they been told that the white race has been the scourge of the earth destroying everything in its path? ... Are your white children being told that they are among a privileged class and that they should be ashamed of their heritage? $h t t p: / / w w w . k k k . b z$ (no longer available)

The site maintained:

“Don't leave your children's moral upbringing to the public school system or the post Christian private school system any longer... Check out our new website and begin making a real meaningful difference in the future of your children!":

$h t t p: / / w w w . k k k . b z$ (no longer available).

For further discussion, see Waltman (2003).

Via the Internet, hate organizations resort to various methods to appeal to potential supporters and recruit them to activities. eNationalist is one racist discussion forum used for exchange of ideas and recruitment. It declares itself

"community for the European and the European descendent".

http://enationalist.com/portal/index (no longer available)

As mentioned above, music plays an important role. When children and youth surf the Internet for music, they may chance on sites that offer hate music, sometimes for free. Such sites are often linked to hate newsgroups and chat rooms for young people. Much of the information is geared especially to teenage and young adult males. ${ }^{6}$

See Shekhvtsov (2013).

One quite popular band was the California Final War which had presence on Yahoo, YouTube and other musical and ideological forums:

http://www.last.fm/music/Final\%20War http://www.youtube.com/watch?v=9pPL1g6MUGk

http://www.musictory.com/music/ Final+War (no longer available)

One Stormfronter wrote:

"their stuff is catchy and I think kids who like some of the newer punkish stuff (like blink 182 and sum 41) would like it a lot. Pretty smart lyrics too":

http://www.stormfront.org/ forum/showthread.php?t=338990

Another Stormfronter commented:
"Theyre a great band... i love the tracks 'Aryan pride' and 'tales of hounor'. The best thing about them is that their music sounds just like standard punk so its easy to listen to and this could help open more peoples eyes to the problems facing our people" (sic.).

http://www.stormfront.org/forum/showthread. php?t=338990

People are invited on LyricsMania to send Final War ringtones to their cells.

http://www.lyricsmania.com/final_war_lyrics.html

Steam has a thriving community dedicated to glorifying and discussing school shootings

Another popular website is The Daily Stormer, a neo-Nazi message board with sarcastic commentary founded in 2013 by 30 -year-old Andrew Anglin, aiming to lure young audience to the white power circles (Lavin, 2018; Wines; Stephanie, 2015). As of April 2018, Alexa ranked the site 24,777 globally and 7,855 within the United States. https://dailystormer.name https://www.alexa.com/siteinfo/dailystormer.name

See also SPLC (n.d.).

Some worry about the connection between white extremist websites and Internet white power music and video entertainment sources, which are filled with racist violence messages. Ray and Marsh argue that white power music is an effective recruitment tool that appeals primarily to disaffected youth (Ray; Marsh II, 2001). There are reports that the two students who attacked Columbine High School were fans of "extreme music" genres known as Gothic / Black metal / Death metal music that is violent and rebellious. ${ }^{7}$

Creativity for Kids is a web site developed by the World

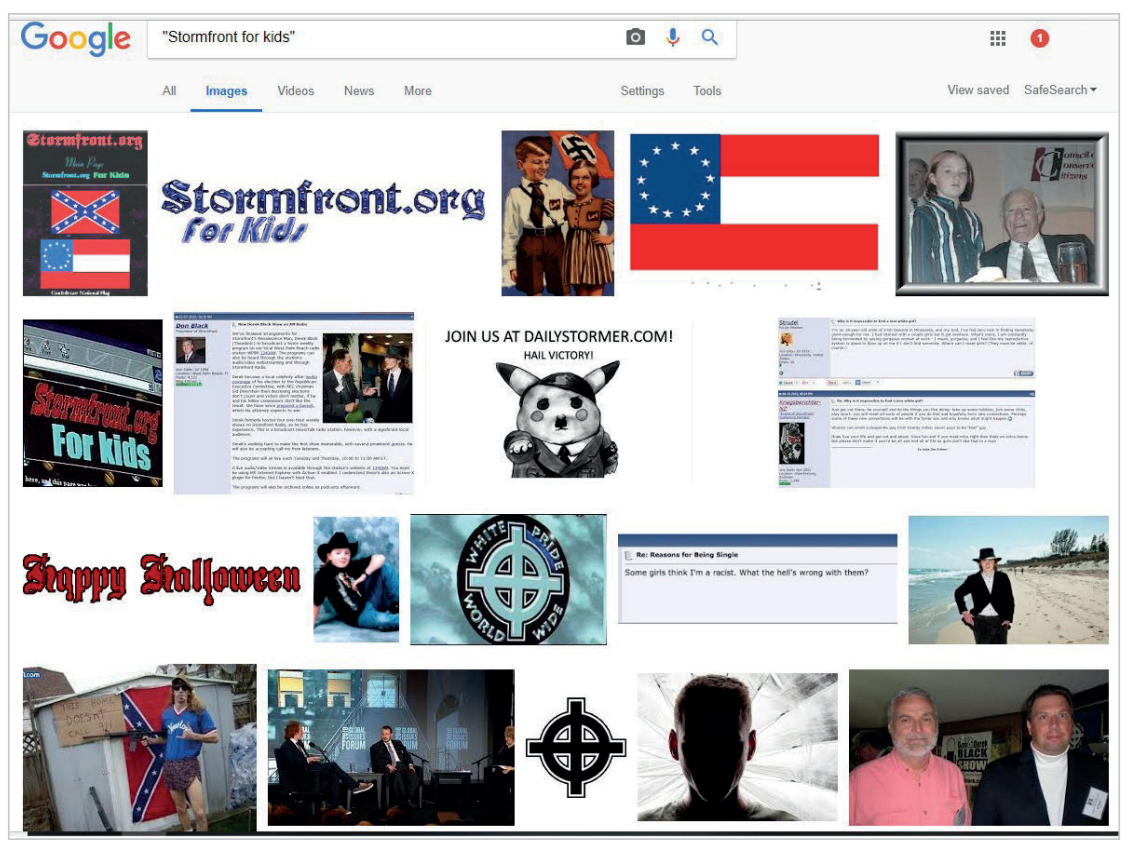

Images from Stormfront for kids 
Church of The Creator (Wcotc) that offers downloadable coloring book pages and crossword puzzles about "white pride" in a subtle "kid-friendly" format. Materials are written at an age-appropriate level. The site invites children to e-mail questions about the online crossword puzzles. While Wcotc packages hate messages within the context of a religion that is anti-Christian, anti-Jewish, and anti-everyone except whites, its children's section mainly promotes white pride. The purpose of the children's section is

"to help the young members of the white race understand our fight" (Ray; Marsh II, 2001).

Stormfront for Kids offers games, optical illusions, a page with the flags of Europe, kaleidoscope painter, information about the history of the white race, and music. Children visiting the page have comprehensive access to all of Stormfront's online materials as well as to its extensive list of external links. The webmaster introduced himself as:

"Derek. I am fifteen years old... I used to be in public school, it is a shame how many White minds are wasted in that system. I am now in home school. I am no longer attacked by gangs of non-whites and I spend most of my day learning, instead of tutoring the slowest kids in my class. In addition to my schoolwork, I am also learning pride in myself, my family and my people". http://www.stormfront.org/kids

For further discussion on Derek Black, see Saslow (2016), Lambert (2017), and "Why I left White nationalism - By Derek Black"

http://forums.sherdog.com/threads/why-i-left-whitenationalism-by-derek-black-stormfront-owners-son.3644489

The Aryan Nations Youth Corps (Anyac) site aims to

"get the message of Yahweh God to all the White, Aryan Youths of America".

It explains that

"Aryan Nations seeks to regenerate all Aryan Youths to their God ordained mission, the education and survival of Our Glorious Aryan Race. For in the Youth lies the next generation of leaders that will bring us closer to the UItimate Victory Day!".

The site calls upon "all male Aryan Youths" to form their own branch of Anyac in their state and town, declaring that

"The time to make a stand is long overdue. We must educate ourselves and those around us to the truths contained in The Holy Bible, and to expose the Jews for who they are (the literal Children of Satan)"

http://aryan-nation.org

On the site you find its Code of Honour, the Aryan Nations symbol and credo, what they are up against (unhealthy minds, drugs, race mixing, abortion, pollution, immigration, multiculturalism, and affirmative action), and a photo of Adolf Hitler.

Young people may be susceptible to online racist propaganda because they do not have the experience or facts at hand to refute the lies and myths being fed to them. Lonely, marginalized youth, seeking a sense of identity and

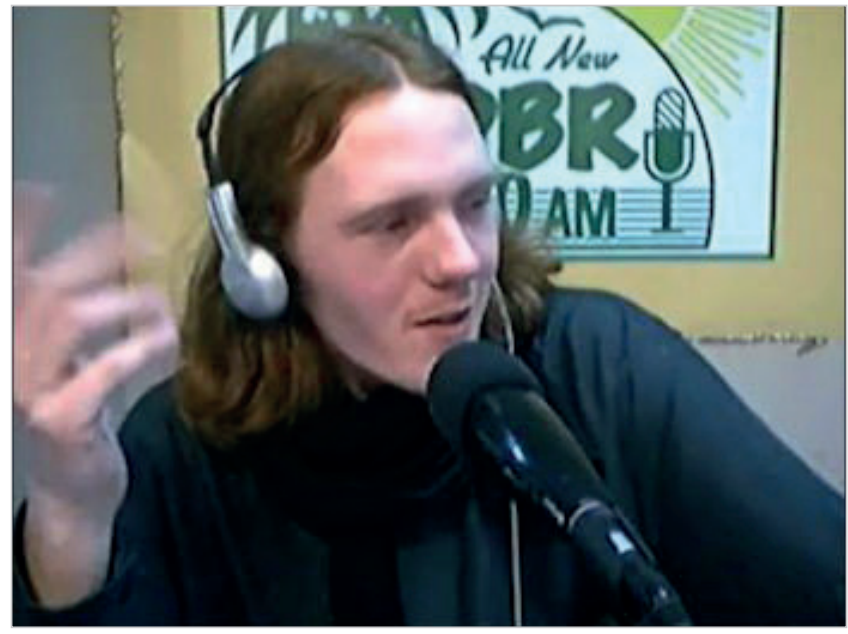

Derek Black

http://www.browardpalmbeach.com

belonging, are both the most attractive targets for racists and their most useful tools, once recruited. Lee and Leets found that storytelling-style, implicit messages often used by hate groups on the Internet were more persuasive to adolescents, who have become the target of new member recruitment of many hate organizations (Lee; Leets, 2002).

Lonely, marginalized youth, seeking a sense of identity and belonging, are both the most attractive targets for racists and their most useful tools

\section{Incitement and blood libels}

Jewish ritual murder argues that the two principal feastdays associated with Jewish ritual murder have been Purim and Passover:

"When a ritual murder occurred at Purim, it was usuaIly that of an adult Christian who was murdered for his blood; it is said that the blood was dried and the powder mixed into triangular cakes for eating; it is possible that the dried blood of a Purim murder might sometimes be used for the following Passover. When a ritual murder was done at Passover, it was usually that of a child under seven years old, as perfect a specimen as possible, who was not only bled white, but crucified, sometimes circumcised and crowned with thorns, tortured, beaten, stabbed, and sometimes finished off by wounding in the side in imitation of the murder of Christ. The blood taken from the child was mixed either in the powdered state or otherwise into the Passover bread."

Jewish ritual murder:

http://www.churchoftrueisrael.com/streicher/jrm/ chapter04.html (no longer available)

The old-time favourite, The Protocols of the Elders of Zion, is frequently mentioned as a wakening call for "wise" Christians who understand the challenge they are facing and realize that it is time to act "Now!" against the Jewish conspir- 
acy to control the world. The Protocols were and remain the major source for most anti-Semitic conspiracy theories: http://www.iahushua.com/BeWise/protocol.html http://www.jewwatch.com/jew-references-protocols-folder.html http://www.threeworldwars.com/protocols.htm http://www.biblebelievers.org.au/proof.htm http://www.bibliotecapleyades.net/esp_sociopol_zion.htm http://holywar.org

http://www.gwb.com.au/gwb/news/multi/zion.html

Now as in Europe of the 1930s, there are endless discussion on "The Jewish problem" and ways to solve it. There is no lack of euphemisms, finding the "answers" in the most unexpected places. Martinlutherking.org and http://www. mlking.org provide the truth you did not know about the religio-political African-American leader, and the world peace blog is anything but peaceful. Its opening statement is:

"In the $21^{\text {st }}$ Century, as in former times, the biggest problem facing mankind remains the all-encompassing power of the Jews over our lives. This blog explores the ruinous nature of that influence and how it must be rooted out in the interests of a peaceful world":

http://worldpeace-phaedrus.blogspot.com/2008_05_01_ archive.html

Hate sites post reprints of white supremacist articles and essays, such as The Talmud: Judaism's holiest book documented and exposed. Meant to inflame Christians and Muslim by characterizing the Talmud as primarily anti-non-Jewish and filled with "malice", "hate-mongering" and "barbarities", this particularly scurrilous tract wilfully distorts and misrepresents an important religious document while demonstrating a complete lack of understanding of its history, complexity, and role in Jewish religious practice (Kessler, 1999, pp. 4-5). See also: The truth about the Talmud http://talmudical.blogspot.co.uk http://www.missionislam.com/nwo/talmud.htm

The Christian Party

http://www.fathersmanifesto.net/talmud.htm

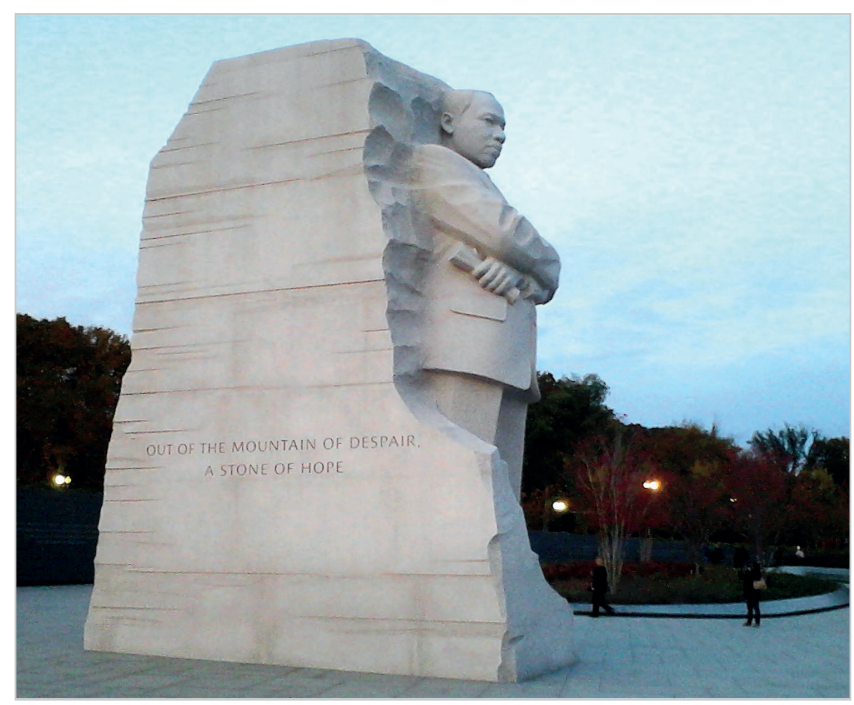

Martin Luther King, Jr. Memorial (U.S. National Park Service)

Located in downtown Washington, D.C., the memorial honors Martin Luther King, Jr.'s legacy and the struggle for freedom, equality, and justice
On the website of the American Nazi Party you can download monumental works, like Adolf Hitler's Mein Kampf, an ideological blueprint for healthy, Aryan survival, and Henry Ford's work on "The international Jew, The world's foremost problem".

http://www.biblebelievers.org.au/intern_jew.htm http://www.americannaziparty.com

The Aryan Unity website of the British People's Party offers masterpieces like Hitler's Mein Kampf and Aryan poetry. http://www.aryanunity.com/poetry.html

The writings of Dr. William Pierce became highly popular within those circles to promote hatred against Jews.

http://natall.com/about/what-we-believe

Pierce's Turner diaries, published in 1978 under the pseudonym Andrew Macdonald, provides a fictional account of a race war by White Supremacists against government officials, intellectuals, Jews and Blacks in order to establish an Aryan world, is glorified and much celebrated:

https://www.amazon.co.uk/Turner-Diaries-AndrewMacdonald/dp/1291531394

https://archive.org/details/TheTurnerDiariesByAndrewMacdonald (no longer available)

It is the most influential tract among right-wing militia circles. Timothy McVeigh, the Oklahoma City bomber, actively promoted the book before the April 1995 bombing that resulted in the death of 168 people ("The Oklahoma City bombing". Indystar.com, August $\left.9^{\text {th }}, 2004\right)$.

McVeigh read carefully Turner's instructions:

"The plan, roughly, is this: Unit 8 will secure a large quantity of explosives-between five and ten tons. Our unit will hijack a truck making a legitimate delivery to the $F B I$ headquarters, rendezvous at a location where Unit 8 will be waiting with the explosives, and switch loads. We will then drive into the $F B I$ building's freight-receiving area, set the fuse, and leave the truck" (Andrew Macdonald, The Turner Diaries, Chapter IV).

Lonely hate mongers find solace on the World Wide Web. Lone-wolf actors create sites with the intention of inspiring further leaderless resistance (Gruen, 2004) (Final report of the Internet Safety Technical Task Force, Enhancing Child Safety and Online Technologies. Boston, Mass.: Berkman Center for Internet and Society, 2008. Appendix C).

One site declares:

"Lone wolves are EVERYWHERE! We are in your: Neighborhoods, Financial Institutions, Police Departments, Military, Social Clubs, Schools. If you would like to be added to the list, send an e-mail to: tm_metzger@yahoo. com and put SUBSCRIBE": White Aryan Resistance http://www.resist.com

For further discussion, see Stewart (2011), Townsend; Pidd (2011); Erlanger; Shane (2011).

\section{Conclusion}

Hate is a powerful emotion. It demands energies and commitment. Hate consumes. It consumes the targets of hatred. It consumes the people who hate. It can become an 
obsession. People who allow themselves to develop hatred towards others move in vicious circles. With the help of the Internet, they find like-minded people and then engage in discussions why their hatred is justified, and what can be done to fight their targets of hate. The entire conversation is negative, dark and destructive. The bigots pump each other with hatred, and push those who are prone to violence to act upon their hatred. Hate speech is conducive to hate crimes.

People who allow themselves to develop hatred towards others move in vicious circles

In 2015, the French government announced a plan to hold web companies accountable for any extremist messages they may host. President Francois Hollande said:

"We must act at the European and international level to define a legal framework so that internet platforms which manage social media be considered responsible, and that sanctions can be taken." (Plaugic, 2015).

On May 31, 2016, the European Commission and some of the major Internet companies announced a new 'Code of conduct on countering illegal hate speech online'. Facebook, Microsoft, Twitter and YouTube have agreed to clarify on their terms of usage that they will prohibit illegal incitement to hatred. They have agreed to introduce clear and effective processes to review and remove or disable access to such content within 24 hours. The new agreement covers illegal incitement to hatred as defined by the Council of the European Union framework decision on combating racism and xenophobia by means of criminal law (2008/913/JHA, 28 November 2008)

"publicly inciting to violence or hatred directed against a group of persons or a member of such a group defined by reference to race, colour, religion, descent or national or ethnic origin":

http://ec.europa.eu/justice/fundamentalrights/files/ hate_speech_code_of_conduct_en.pdf

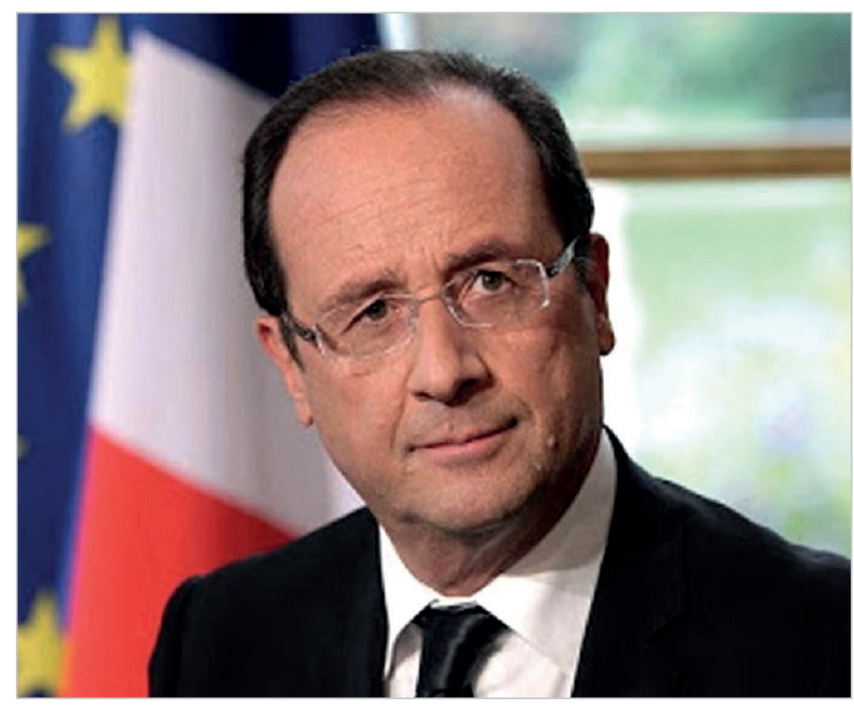

François Hollande, President of France 2012-2017
One year after its adoption, the Code of Conduct on countering illegal hate speech online has delivered some important progress, while some challenges remain:

- On average, in $\mathbf{5 9 \%}$ of the cases, the IT companies responded to notifications concerning illegal hate speech by removing the problematic content.

- The amount of notifications reviewed within 24 hours improved from $40 \%$ to $51 \%$. Facebook is reviewing the majority of notifications within the day.

- The IT companies improved their ability to treat notifications coming from citizens in the same way as those coming from organisations.

- While Facebook sends systematic feedback to users on how their notifications have been assessed, practices differed considerably among the IT companies (European Commission, 2017).

Hate speech on social media has been a major concern of Jewish organisations, chief among them the Anti-Defamation League (Foxman; Wolf, 2013). In his 2018 congressional testimony, Facebook founder Mark Zuckerberg admitted that clearly

"we didn't do enough to prevent these tools from being used for harm."

He estimated that in ten years time, Facebook will have artificial intelligence tools that can get into some of the linguistic nuances of different types of content to be more accurate, to be flagging things to the systems, and stop hate speech before it is distributed. Zuckerberg said that today "we are just not there on that". It is reassuring to know that this issue is now of priority for Facebook. ${ }^{8}$ For too many long years, this was not the case.

\section{Notes}

1. Unless said otherwise, all websites were accessed during April 2018.

2. E.g., Terminiello v. Chicago, 337 U.S. 1 (1949); Beauharnais v. Illinois, 343 U.S. 250 (1952); Jordan v. Burgoyne 2 QB 744, 1963; Brandenburg v. Ohio, 395 U.S. 444 (1969); Village of Skokie v. NSPA. 366 N.E. 2d 347 (1977); Skokie v. NSPA. 373 N.E. 2d, 21 (1978); Smith v. Collin, 439 U.S. 916 (1978); Land v. The State 262 Ga. 898, 426 S.E.2d 370 (1993).

3. Canada (Human Rights Commission) v. Taylor, [1990] 3 S.C.R. 892.

http://www.canlii.org/ca/cas/scc/1990/1990scc130.html

4. For more information on Don Black and Stormfront, see:

- Prepared Statement of Howard Berkowitz, Hate Crime on the Internet, Hearing before the Committee on the Judiciary, United States Senate, Washington, September 14th.

- Marriott, Michael (1999). "Rising tide: Sites born of hate". The New York Times, March $18^{\text {th }}$.

- "Don Black/Stormfront", ADL. https://www.adl.org/sites/default/files/documents/ assets/pdf/combating-hate/Don-Black.pdf

5. "Early racist and antisemitic bulletin board systems (BBS)". Political Research Associates.

http://www.publiceye.org/hate/earlybbs.html 
6. HATE IN AMERICA, Part 3: The Psychology and Recruitment of Hate (February 12, 2010).

http://planetpov.com/2010/02/12/hate-in-america-part-3the-psychology-and-recruitment-of-hate

7. Prepared Statements of Joseph T. Roy Sr. and Howard Berkowitz, Hate Crime on the Internet, Hearing before the Committee on the Judiciary, United States Senate (Washington, September 14, 1999).

8. "Mark Zuckerberg: Facebook will predict hate speech content within the next decade". Jewish Telegraphic Agency, April 10, 2018.

https://www.jta.org/2018/04/10/news-opinion/politics/ mark-zuckerberg-facebook-will-predict-hate-speechcontent-within-next-decade

\section{References}

Bartlett, Jamie (2017). "From hope to hate: how the early Internet fed the far right". The Guardian, August $31^{\text {st }}$. https://www.theguardian.com/world/2017/aug/31/farright-alt-right-white-supremacists-rise-online

Berlet, Chip (2000). "When hate went online". PublicEye. org, July.

http://www.publiceye.org/hate/online_85/racist_bbs.html

Bowman-Grieve, Lorraine (2009). "Exploring 'Stormfront': A virtual community of the radical right". Studies in conflict \& terrorism, v. 32, n. 11, pp. 989-1007.

https://doi.org/10.1080/10576100903259951

Carless, Will; Sankin, Aaron (2018). "Hate report: gaming app has 173 groups that glorify school shooters". Reveal news, March $2^{\text {nd }}$.

https://www.revealnews.org/blog/hate-report-gamingapp-has-173-groups-that-glorify-school-shooters

Cohen-Almagor, Raphael (2009). "Holocaust denial is a form of hate speech". Amsterdam law forum, v. 2, n. 1, pp. 33-42. http://ojs.ubvu.vu.nl/alf/article/view/105/188

Cohen-Almagor, Raphael (2010). "Countering hate on the Internet -A rejoinder". Amsterdam law forum, v. 2, n. 2, pp. 125-132.

http://ojs.ubvu.vu.nl/alf/article/view/138/264

Cohen-Almagor, Raphael (2011). "Fighting hate and bigotry on the Internet". Policy and internet, v. 3, n. 3, article 6. https://doi.org/10.2202/1944-2866.1059

Cohen-Almagor, Raphael (2012). "Freedom of expression, internet responsibility and business ethics: The Yahoo! saga and its aftermath". Journal of business ethics, v. 106, n. 3, pp. 353-365.

https://doi.org/10.1007/s10551-011-1001-z

Cohen-Almagor, Raphael (2014). "Countering hate on the Internet". Annual review of law and ethics, v. 22, pp. 431-443. https://www.researchgate.net/publication/270276295_ Countering_Hate_on_the_Internet

Cohen-Almagor, Raphael (2015). Confronting the Internet's dark side: Moral and social responsibility on the free highway. NY and Washington DC.: Cambridge University Press and Woodrow Wilson Center Press. ISBN: 9781107513471
Cohen-Almagor, Raphael (2016). "Facebook and Holocaust denial". Justice, v. 57, pp. 10-16.

https://www.researchgate.net/publication/299506564_ Facebook_and_Holocaust_Denial

Cohen-Almagor, Raphael (2018). "Taking North American white supremacist groups seriously: The scope and the challenge of hate speech on the Internet". International journal of crime, justice, and social democracy, v. 7, n. 2, pp. 38-57. https://hull-repository.worktribe.com/OutputFile/602877

Delgado, Richard; Stefancic, Jean (2004). Understanding words that wound. Boulder, CO: Westview, p. 24. ISBN: 978 0813341392

Dickson, Caitlin (2014). "Where white supremacists breed online". The daily beast, April $17^{\text {th }}$.

https://goo.gl/GfScD3

Erlanger, Steven; Shane, Scott (2011). "Oslo suspect wrote of fear of Islam and plan for war". The New York Times, July $23^{\text {rd }}$. http://www.nytimes.com/2011/07/24/world/europe/24oslo. html?nl=todaysheadlines\&emc=tha2

European Commission (2017). Countering online hate speech - Commission initiative with social media platforms and civil society shows progress. Press release, Brussels, June $1^{\text {st }}$. http://europa.eu/rapid/press-release_IP-17-1471_en.htm

Foxman, Abraham H. (2014). “Facebook makes wrong call on anti-Semitic page". Cnet.com, March $15^{\text {th }}$.

http://news.cnet.com/8301-1023_3-57620374-93/ facebook-makes-wrong-call-on-anti-semitic-page

Foxman, Abraham H.; Wolf, Christopher (2013). Viral hate. NY: Palgrave-Macmillan. ISBN: 9780230342170 https://doi.org/10.1111/1478-9302.12087_70

Fuchs, Christian (2014). Social media: A critical introduction. London: Sage. ISBN: 9781473987494

Gerstenfeld, Phyllis B. (2017). Hate crimes: Causes, controls, and controversies. Thousand Oaks, Ca.: Sage. ISBN: 9781452256627

Gerstenfeld, Phyllis B.; Grant, Diana R.; Chiang, Chau-Pu (2003). "Hate online: A content analysis of extremist internet sites". Analyses of social issues and public policy, v. $3, \mathrm{n}$. 1, pp. 29-44.

https://doi.org/10.1111/j.1530-2415.2003.00013.x

Goldstein, Hilary (2009). "Editorial: Is Resident evil 5 racist?". IGN, March $13^{\text {th }}$.

http://uk.xbox360.ign.com/articles/953/953114p1.html

Gruen, Madeleine (2004). "White ethnonationalist and political Islamist methods of fund-raising and propaganda on the Internet". In: Rohan Gunaratna (ed.). The changing face of terrorism. Singapore: Marshall Cavendish, p. 127. ISBN: 9789812104465

Hamm, Mark S. (1993). American skinheads: The criminology and control of hate crime. Westport, CT.: Praeger. ISBN: 9780275949877

Hoffman, David S. (1996). The web of hate: Extremists exploit the Internet. New York: Anti-Defamation League, p. 9. https://goo.gl/z3HwXL 
Kaplan, Jeffrey (1995). "Right wing violence in North America". Terrorism and political violence, v. 7, n. 1, pp. 44-95. https://doi.org/10.1080/09546559508427285

Keats-Citron, Danielle (2014). Hate crimes in cyberspace. Cambridge, Mass.: Harvard University Press. ISBN: 9780 674659902

Kessler, Jordan (1999). Poisoning the Web: Hatred online. New York: Anti-Defamation League, p. 53. http://www.metal-archives.com/labels/Resistance_Records/642

KhosraviNik, Majid; Unger, Johann W. (2015). "Critical discourse studies and social media: Power, resistance and critique in changing media ecologies". In: Ruth Wodak and Michael Meyer (eds.). Methods of critical discourse studies. Thousand Oaks, Ca.: Sage. ISBN: 9780761961536

Lambert, Olivia (2017). "White nationalist future leader turns back on movement". News.com, August $28^{\text {th }}$. https://goo.gl/9tJyQy

Lavin, Talia (2018). "The neo-Nazis of the Daily Stormer wander the digital wilderness". The New Yorker, January $7^{\text {th }}$. https://www.newyorker.com/tech/elements/the-neo-nazisof-the-daily-stormer-wander-the-digital-wilderness

Lee, Elissa; Leets, Laura (2002). "Persuasive storytelling by hate groups online. Examining its effects on adolescents". American behavioral scientist, v. 45, n. 6, pp. 927-957. https://doi.org/10.1177/0002764202045006003

Man, Incog (2009). "Columbine: 10 years of Jew media lies". Incog.man, April $20^{\text {th }}$.

http://incogman.net/2009/04/columbine-10-years-of-jewmedia-lies

Matas, David (1997). "Countering hate on the internet: recommendations for action". Media Awareness Network.

Plaugic, Lizzie (2015). "France wants to make Google and Facebook accountable for hate speech". The verge, January $27^{\text {th }}$. http://www.theverge.com/2015/1/27/7921463/googlefacebook-accountable-for-hate-speech-france

Potok, Mark (2015). Carnage in Charleston. Southern Poverty Law Center, October $27^{\text {th }}$.

https://www.splcenter.org/fighting-hate/intelligencereport/2015/carnage-charleston

Ray, Beverly; Marsh II, George E. (2001). "Recruitment by extremist groups on the Internet". First Monday, v. 6, n. 2, February $5^{\text {th }}$. http://ojphi.org/ojs/index.php/fm/article/view/834/743

Roversi, Antonio (2008). Hate on the Net. Aldershot: Ashgate, pp. 93-94. ISBN: 9780754672142

Sandberg, Jared (1994). "Net results: Some nasty creatures in cyberspace". Globe and mail, December $13^{\text {th }}$.
Shekhvtsov, Anton (2013). "European far-right music and its enemies". In: Ruth Wodak and John E. Richardson (eds.). Analysing fascist discourse. NY and London: Routledge, pp. 277-296. ISBN: 9780415899192

Stephens-Davidowitz, Seth (2014). "The data of hate". The NY Times, July $12^{\text {th }}$.

http://www.nytimes.com/2014/07/13/opinion/sunday/ seth-stephens-davidowitz-the-data-of-hate.html

Stern, Kenneth S. (2001-2002). "Hate and the Internet". Journal of hate studies, v. 1, p. 61.

Terdiman, Daniel (2004). "Playing games with a conscience". Wired, April 22 ${ }^{\text {nd }}$.

https://www.wired.com/2004/04/playing-games-with-aconscience

Tworek, Heidi (2017). "How Germany is tackling hate speech". Foreign affairs, May $16^{\text {th }}$.

https://www.foreignaffairs.com/articles/germany/2017-05-16/ how-germany-tackling-hate-speech

Saslow, Eli (2016). "The white flight of Derek Black". The Washington Post, October $17^{\text {th }}$.

https://goo.gl/BGZzzZ

SPLC (n.d.). Andrew Anglin. Southern Poverty Law Center. https://www.splcenter.org/fighting-hate/extremist-files/ individual/andrew-anglin

Stewart, Scott (2011). “Norway: Lessons from a successful lone wolf attacker". Stratfor, July $28^{\text {th }}$.

https://goo.gl/VzJkMv

Townsend, Mark; Pidd, Helen (2011). “Anders Behring Breivik: 'I'm surprised I wasn't stopped'". The guardian, July $27^{\text {th }}$. https://www.theguardian.com/world/2011/jul/26/norwaykiller-breivik-surprised-stopped

Vaughan, Carson (2017). "The Farm Belt führer: The making of a neo-Nazi". The guardian, July $6^{\text {th }}$.

https://www.theguardian.com/world/2017/jul/06/neonazi-gerhard-lauck-nebraska-antisemitism

Waltman, Michael S. (2003). "Stratagems and heuristics in the recruitment of children into communities of hate: The fabric of our future nightmares". The Southern communication journal, v. 69, n. 1, pp. 22-36. https://doi.org/10.1080/10417940309373276

Werts, Diane (2000). "How the Web spawns hate and violence". Newsday, October $23^{\text {rd }}$, B27.

Wines, Michael; Stephanie, Saul (2015). "White supremacists extend their reach through websites". The NY Times, July $5^{\text {th }}$.

https://goo.gl/iASxVs 